\title{
Stimulation of 2-deoxyglucose uptake in rat adipocytes by a human growth hormone fragment (hGH 4-15)
}

\author{
F. M. Ng and J.A. Harcourt \\ Department of Biochemistry, Monash University, Clayton, Victoria, Australia
}

\begin{abstract}
Summary. The in vivo and in vitro effects of a hypoglycaemic fragment of human growth hormone containing the sequence $\mathrm{H}_{2} \mathrm{~N}$-Ile-Pro-Leu-Ser-Arg-Leu-Phe-Asp-Asn-Ala-Met-Leu$\mathrm{COOH}$ (hGH 4-15) on 2-deoxy-[1- $\left.{ }^{14} \mathrm{C}\right]-\mathrm{D}$-glucose uptake in adipocytes were studied. The isolated cells from rats after a single intravenous injection of hGH $4-15(1 \mathrm{mg} / \mathrm{kg})$ significantly increased uptake of 2-deoxyglucose $(p<0.005)$. Adipocytes from untreated rats pre-incubated with the hGH fragment $(10 \mu \mathrm{g} / \mathrm{ml})$ at $37^{\circ} \mathrm{C}$ for $30 \mathrm{~min}$ also clearly showed an elevated uptake of 2-deoxyglucose in the absence and the
\end{abstract}

presence of exogenous insulin. The effect of hGH 4-15 was concentration-dependent, steadily increasing with the maximum effect at $10 \mu \mathrm{g} / \mathrm{ml}$. The present findings suggest that the enhancement of glucose transport in target tissues may be a major contributing factor to the hypoglycaemic action of the amino-terminal fragments of human growth hormone.

Key words: Human growth hormone synthetic fragment 4-15, glucose transport, rat adipocytes.
Growth hormone $(\mathrm{GH})$ displays a great variety of biological activities in vivo and in vitro. Hypoglycaemic activity of GH has long been documented [1] and has been shown to be due to insulin-synergistic action of the melecule [2]. The molecular mechanisms underlying the diverse in vivo actions of the hormone remain poorly understood, although many hypotheses have currently been proposed. The hypothesis that structural variants or discrete regions of the $\mathrm{GH}$ molecule are responsible for different biological actions is supported by a reasonable amount of experimental evidence [3-6]. Studies with synthetic fragments of human growth hormone $(\mathrm{hGH})$ suggest that the amino-terminal region of the molecule constitutes the active centre of the hormone for hypoglycaemic action [7-10]. A comparative study of hypoglycaemic responses in rats with low circulating levels of $\mathrm{GH}$ revealed that both the intact molecule and the synthetic hGH 4-15 fragment affected the animals in an identical manner [11]. Hypoglycaemia represents only the end point of what must be a complex series of cellular and biochemical events. Evidence so far indicates that synthetic fragments of hGH containing the active sequence $\mathrm{H}_{2} \mathrm{~N}$-Arg-Leu-Phe-Asp-Asn-Ala$\mathrm{COOH}$ induced hypoglycaemia as the result of modulating insulin receptor function and intracellular enzymic activities [12-17].

The present study was initiated to examine the effect of the hypoglycaemic hGH 4-15 on the glucose transport system, which is known as a major membrane regulatory component for overall glucose metabolism in target tissues. Impairment in glucose transport has been reported as a possible mechanism of insulin resistance in adipocytes of diabetic rats [18]. Furthermore, previous studies on glucose metabolism cannot be taken as a measure of glucose transport, since enhanced utilization of glucose by the activation of intracellular enzymes such as glycogen synthase has been shown to be independent of glucose transport [19-21].

\section{Materials and methods}

\section{Chemicals}

Peptide hGH 4-15 was synthesized and purified as previously described [15]. Purified crystalline beef insulin was purchased from Commonwealth Serum Laboratories (Melbourne, Australia), bovine serum albumin (fraction V), trypsin and cytochalasin B from Sigma (St. Louis, Mo, USA), rabbit anti-insulin anti-serum $(2 \mu \mathrm{l} / \mathrm{U} / \mathrm{ml})$ from Miles Laboratories (Melbourne, Australia), collagenase (type 1) and neuraminidase from Worthington (Freehold, NJ, USA), $\left[\mathrm{U}_{-}{ }^{14} \mathrm{C}\right]-\mathrm{D}-$ glucose $(230 \mathrm{mCi} / \mathrm{mmol})$, 2-deoxy-[1- $\left.{ }^{14} \mathrm{C}\right]-\mathrm{D}$-glucose $(50 \mathrm{mCi} / \mathrm{mmol})$, [1- $\left.{ }^{3} \mathrm{H}(\mathrm{N})\right]-\mathrm{D}$-Sorbitol $(15 \mathrm{Ci} / \mathrm{mmol})$ and $\left[{ }^{3} \mathrm{H}\right]$-inulin $(5 \mathrm{Ci} / \mathrm{mmol})$ were from the Radiochemical Centre (Amersham, UK).

\section{Animals}

Male albino wistar rats of $100-120 \mathrm{~g}$, housed under conditions of constant temperature $\left(25^{\circ} \mathrm{C}\right)$ with normal 12-h light cycle and fed ad libitum, were used for the present work. For in vitro experiments animals were stunned by a blow to the head, decapitated, and epididymal fat pads removed for tissue experiments or preparations of isolated adipocytes. For the studies of the in vivo effects of hGH 4-15, animals 
were anaesthesized with an intraperitoneal injection of sodium pentobarbital $(5 \mathrm{mg} / 100 \mathrm{~g}$ body $\mathrm{wt}) 30 \mathrm{~min}$ prior to experimentation. The anaesthetized animals were then given intravenously a predetermined dose of the synthetic hGH fragment or saline (as control) for the indicated period of time before killing for tissue or cell preparations.

\section{Preparation of isolated adipocytes}

Isolated adipocytes were prepared from epididymal fat pads of control and hGH 4-15 treated rats by the method of Rodbell [22]. Adipocyte counts were performed according to the procedure as described by Foley et al. [23].

\section{Metabolism of glucose}

The distal portions of epididymal fat pads were dissected into segments and incubated at $37^{\circ} \mathrm{C}$ for $45 \mathrm{~min}$ in Krebs-Ringer bicarbonate buffer ( $\mathrm{pH} 7.4)$ containing $\left[\mathrm{U}_{-}{ }^{14} \mathrm{Cl}-\mathrm{D}\right.$-glucose $(5 \mu \mathrm{Ci} / \mu \mathrm{mol})$, insulin and hGH 4-15 as indicated. $\left[{ }^{14} \mathrm{ClO}_{2}\right.$ production was measured as follows in the studies of glucose oxidation. The incubation was terminated by the injection of $200 \mu \mathrm{l}$ of $5 \mathrm{M} \mathrm{H}_{2} \mathrm{SO}_{4}$ through a rubber seal into the incubation vial. Immediately $200 \mu$ of hyamine hydroxide was injected onto a filter paper in the hanging well of the vial to collect the $\left[{ }^{14} \mathrm{C}^{\mathrm{O}} \mathrm{O}_{2}\right.$ released. After a further incubation at $37^{\circ} \mathrm{C}$ for $60 \mathrm{~min}$, the filter paper roll was removed from the hanging well for radioactivity determination in a liquid scintillation counter. The similar incubation procedure was used for the estimation of glucose incorporation into lipid, $\left[{ }^{14} \mathrm{C}\right.$-lipid in the tissues was extracted with $5 \mathrm{ml}$ of chloroform: methanol $(2: 1)$ overnight at $4{ }^{\circ} \mathrm{C}$. The fat pads were re-extracted twice with $2.5 \mathrm{ml}$ of solvent mixture for $2 \mathrm{~h}$. Non-lipid contaminants were removed by washing with methanol containing $0.005 \% \mathrm{MgCl}_{2}$ according to the method of Folch et al. [24]. The purified lipid extract was evaporated to dryness in a counting vial. Toluene scintillator was added and radioactivity was determined in a LKB liquid scintillation counter. Corrections for quenching were obtained by counting aliquots of different size and extrapolating to zero sample concentration as described by Jungas [25]. For enzyme assays, adipose tissues or isolated adipocytes were extracted by homogenization in a $\mathrm{pH} 7.6 \mathrm{buffer}$ containing $50 \mathrm{mmol} / 1$ triethanolamine hydrochloride, $5 \mathrm{mmol} / \mathrm{l}$ EDTA, $25 \mathrm{mmol} / 1 \mathrm{NaF}$ and $5 \mathrm{mmol} / \mathrm{l}$ 2-mercaptoethanol [26]. The supernatants were used for the determinations of glycogen synthase activity as described by Newman et al. [27].

\section{Glucose transport studies}

Glucose transport in adipocytes was studied by using 2-deoxy- $\left[1-{ }^{14} \mathrm{C}\right]-$ D-glucose. To determine the basal or insulin-stimulated glucose transport in adipocytes from control and hGH 4-15 treated animals, suspensions at a concentration of $3-4 \times 10^{5}$ cells $/ \mathrm{ml}$ were pre-incubated in the absence or the presence of insulin $(10 \mu \mathrm{U} / \mathrm{ml})$ at $25^{\circ}$ for $45 \mathrm{~min}$ before assays. To test the in vitro effect of the hGH 4-15, normal adi- pocytes were pre-incubated with or without the hGH fragment $(10 \mu \mathrm{g} / \mathrm{ml})$ at $37^{\circ} \mathrm{C}$ for $30 \mathrm{~min}$. At the end of the pre-incubation the cells were washed and further incubated at $25^{\circ} \mathrm{C}$ for $45 \mathrm{~min}$ in the absence of the presence of insulin $(10 \mu \mathrm{U} / \mathrm{ml})$. The washing step would eliminate the possible molecular interaction between the hGH pep tide and insulin, and it was necessary in the examination of the direct modulating action of hGH 4-15 on target cells. The assays were begun by adding $20 \mu \mathrm{l}$ of radioactive labelled 2-deoxyglucose (final concentration $0.125 \mathrm{mmol} / \mathrm{l}$ ) to the cells in $230 \mu \mathrm{l}$ of Krebs-Ringer bicarbonate buffer containing $1 \%$ albumin. After incubation at $25^{\circ} \mathrm{C}$ for $5 \mathrm{~min}$, the hexose uptake was terminated by rapidly transferring $200 \mu 1$ aliquots from the assay mixture to plastic microfuge tubes containing $100 \mu 1$ of dinonylphthalate. The tubes were centrifuged for $30 \mathrm{~s}$ in a Beckman microfuge and the assay was considered terminated when centrifugation began. The microfuge tubes were sliced at the viscous oil layer, and the radioactivity associated with the packed cells in the top layer was measured as described by Kobayashi and Olefsky [28]. The amount of 2-deoxy-[1-14 C]-D-glucose trapped in the extracellular water space of the cell layers was determined with $\left[{ }^{3} \mathrm{H}\right]$ sorbitol or $\left[{ }^{3} \mathrm{H}\right]$ insulin according to the method of Gliemann [29]. All data for 2-deoxy-[1- $\left.{ }^{14} \mathrm{C}\right]-\mathrm{D}$-glucose transport were corrected for this factor.

\section{Statistical analysis}

Values are given as means \pm SEM. Differences between means were analyzed with student's t-test for multiple comparisons and $p$ values $<0.05$ were considered significant.

\section{Results}

\section{Effect of hGH 4-15 on glucose metabolism in adipose tissues and isolated adipocytes}

Glucose oxidation, glycogen synthase activation and glucose incorporation into total lipid were increased after a single intravenous injection of hGH $4-15$ (1 mg/ $\mathrm{kg}$ ) as shown in Table 1. The increase in the metabolic activities of the hGH 4-15 treated adipose tissues assayed under basal conditions revealed the in vivo metabolic modulation by the hGH fragment, possibly via endogenous insulin, as we had previously observed no effect of the hGH fragments in the streptozotocin-diabetic rats with undetectable levels of endogenous insulin [8]. The adipose tissues from hGH 4-15 treated animals were clearly more active in the three parameters tested in the presence of insulin; the percentage increase over the respective controls are $189 \%$ for glu-

Table 1. In vivo effect of hGH 4-15 on glucose oxidation, glycogen synthase activation and glucose incorporation into lipid in adipose tissues

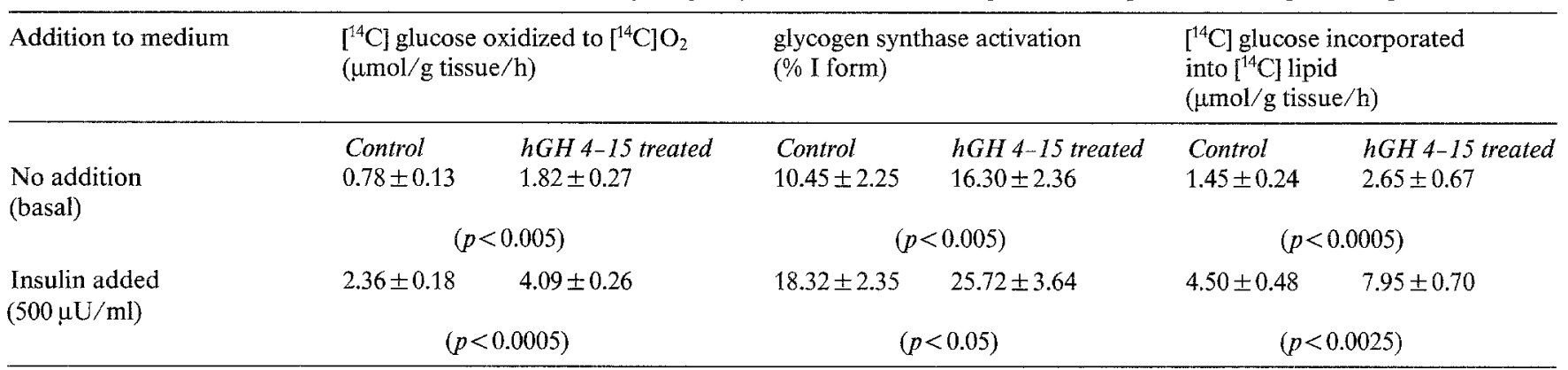

Anaesthetized rats were intravenously injected with hGH $4-15(1 \mathrm{mg} / \mathrm{kg}$ ) or equivalent volume of saline (as control). After $30 \mathrm{~min}$ adipose tissues were removed and incubated with $1 \mathrm{mmol} / 1\left[\mathrm{U}-{ }^{14} \mathrm{C}\right]-\mathrm{D}$-glucose at $37^{\circ} \mathrm{C}$ for $45 \mathrm{~min}$ in the absence (basal) and presence of insulin $(500 \mu \mathrm{U} / \mathrm{ml})$. The glucose oxidation, glycogen synthase activation and lipogenesis were determined as indicated in Materials and methods. Results are the means \pm SEM of 5 separate experiments. Three animals in each of the control and test groups were used in every experiment 
Table 2. In vitro effect of hGH 4-15 on glucose oxidation and glycogen synthase activation in isolated adipocytes

\begin{tabular}{lll}
\hline Addition to medium & $\begin{array}{l}{ }^{[4} \mathrm{Cl} \text { glucose oxidised } \\
\text { to }\left[{ }^{14} \mathrm{C} \mathrm{O}_{2}\right. \\
\left(\mu \mathrm{mol} / 10^{6} \text { cells/h) }\right.\end{array}$ & $\begin{array}{l}\text { Glycogen synthase } \\
\text { activation } \\
(\% \mathrm{I} \text { form })\end{array}$ \\
\hline $\begin{array}{l}\text { No addition } \\
\text { (basal) }\end{array}$ & $0.051 \pm 0.014$ & $11.25 \pm 2.84$ \\
$\mathrm{hGH} 4-15$ & $0.096 \pm 0.023$ & $19.40 \pm 3.62$ \\
$(10 \mu \mathrm{g} / \mathrm{ml})$ & $\begin{array}{l}(p<0.05) \\
(p<0.05)\end{array}$ \\
$\begin{array}{l}\text { Insulin } \\
(100 \mu \mathrm{U} / \mathrm{ml})\end{array}$ & $0.222 \pm 0.046$ & $25.31 \pm 3.47$ \\
Insulin & $0.385 \pm 0.067$ & $38.74 \pm 4.55$ \\
$(100 \mu \mathrm{U} / \mathrm{ml})+$ & $(p<0.02)$ & \\
$\mathrm{hGH} 4-15$ & & \\
$(10 \mu \mathrm{g} / \mathrm{ml})$ & &
\end{tabular}

Isolated adipocytes from normal rats were pooled and incubated with $0.1 \mathrm{mmol} / 1\left[\mathrm{U}-{ }^{14} \mathrm{C}\right]-\mathrm{D}$-glucose at $37^{\circ} \mathrm{C}$ for $30 \mathrm{~min}$ in the absence and presence of hGH $4-15(10 \mu \mathrm{g} / \mathrm{ml})$ or insulin $(100 \mu \mathrm{U} / \mathrm{ml})$ or insulin plus hGH 4-15 as indicated. Glucose oxidation and glycogen synthase activation were determined as described in Materials and methods. Data represents the mean \pm SEM of five separate experiments each done in triplicate

Table 3. In vivo and in vitro effects of hGH $4-15$ on 2-deoxy- $\left[1-{ }^{14} \mathrm{C}\right]-$ D-glucose transport in isolated adipocytes

\begin{tabular}{|c|c|c|c|}
\hline \multirow[t]{2}{*}{ Experiment } & \multirow[t]{2}{*}{ Conditions } & \multicolumn{2}{|c|}{$\begin{array}{l}\text { 2-deoxy-[1-14 } \mathrm{C}]-\mathrm{D} \text {-glucose uptak } \\
\left(\mathrm{mmol} / 10^{5} \text { cells } / 5 \mathrm{~min}\right)\end{array}$} \\
\hline & & Basal & $\begin{array}{l}\text { Insulin } \\
(10 u(\mathrm{ml})\end{array}$ \\
\hline \multirow[t]{2}{*}{ In vivo } & Control & $0.414 \pm 0.052$ & $0.566 \pm 0.089$ \\
\hline & $\begin{array}{l}\text { hGH } 4-15 \text { treated } \\
(1 \mathrm{mg} / \mathrm{kg})\end{array}$ & $\begin{array}{l}0.722 \pm 0.100 \\
(p<0.005)\end{array}$ & $\begin{array}{l}0.898 \pm 0.112 \\
(p<0.0015)\end{array}$ \\
\hline \multirow[t]{2}{*}{ In vitro } & Control & $0.334 \pm 0.042$ & $0.546 \pm 0.069$ \\
\hline & $\begin{array}{l}\text { hGH } 4-15 \text { added } \\
(10 \mu \mathrm{g} / \mathrm{ml})\end{array}$ & $\begin{array}{l}0.638 \pm 0.071 \\
(p<0.002)\end{array}$ & $\begin{array}{l}0.860 \pm 0.102 \\
(p<0.010)\end{array}$ \\
\hline
\end{tabular}

To determine the in vivo effect of hGH $4-15$ on 2 -deoxy- $\left[1-{ }^{14} \mathrm{C}\right]-\mathrm{D}$ glucose transport, adipocytes were isolated from control and test animals treated in the identical manner as described for Table 1 . Suspensions at a concentration of $3-4 \times 10^{5}$ cells $/ \mathrm{ml}$ were pre-incubated in the absence or the presence of insulin $(10 \mu \mathrm{U} / \mathrm{ml})$ at $25^{\circ} \mathrm{C}$ for $45 \mathrm{~min}$ before assays. The in vitro effect of the hGH fragment on radioactive labeled 2-deoxyglucose was demonstrated with normal adipocytes pre-incubated with or without hGH $4-15(10 \mu \mathrm{g} / \mathrm{ml})$ at $37^{\circ} \mathrm{C}$ for $30 \mathrm{~min}$. At the end of the preincubation the cells were washed and incubated at $25^{\circ} \mathrm{C}$ an additional $45 \mathrm{~min}$ in the absence or the presence of insulin $(10 \mu \mathrm{U} / \mathrm{ml})$. Assays were begun by adding 2-deoxyglucose at a final concentration of $0.125 \mathrm{mmol} / 1$ and terminated at the end of $5 \mathrm{~min}$ by rapidly transferring $200 \mu \mathrm{l}$ aliquots from the assay mixture to plastic microtube containing $100 \mu \mathrm{l}$ of dionylphthalate for a $30 \mathrm{~s}$ centrifugation in a microfuge. All values are corrected for extracellular water space as indicated in Materials and methods. The data represent the mean \pm SEM of five separate experiments performed in quadruplicate

cose oxidation, $120 \%$ for glycogen synthase activation and $173 \%$ for glucose incorporation into lipid. The hGH 4-15 treated adipose tissues appeared to have a significantly high level of the active form (I) of glycogen synthase even when assayed under basal condition $(p<0.005)$. This is similar to our previous observation in skeletal muscle [12]. Table 2 reveals the in vitro actions of $\mathrm{hGH} 4-15$. The $\mathrm{hGH}$ peptide $(10 \mu \mathrm{g} / \mathrm{ml})$ significantly increased glucose oxidation and glycogen synthase activation in isolated adipocytes both in the presence and the absence of exogenous insulin $(p<0.05)$.

\section{Effect of hGH 4-15 on 2-deoxy-D- $\left.\mathcal{I}^{14} C\right]$ glucose transport in isolated adipocytes}

The in vivo and in vitro effects of hGH 4-15 on 2-deoxy- $\left[1-{ }^{14} \mathrm{C}\right]-\mathrm{D}$-glucose transport in adipocytes were demonstrated under basal conditions and in the presence of $10 \mu \mathrm{U} / \mathrm{ml}$ of insulin (Table 3 ). The experimental conditions for the measurements of 2 -deoxy- $\left[1-{ }^{14} \mathrm{C}\right]-\mathrm{D}$ glucose transport were previously established in a separate study (Harcourt, M.Sc. thesis, Monash University, 1984) to ensure that phosphorylation was not the limiting step in the uptake of the glucose analogue. Hexokinase activity in adipocyte homogenates as measured with the method described by May and Mikulecky [30] was $2.4 \pm 0.5 \mathrm{mU} / 10^{5}$ cells, which remained unchanged in the cells during the initial 20 min of incubation, and was substantially higher than the rate of uptake of $2-$ deoxy-[1- $\left.{ }^{14} \mathrm{C}\right]-\mathrm{D}$-glucose under the experimental conditions used for present studies. In addition, the intracellular contents of 2-deoxy-[1-14 C]-D-glucose and 2deoxy-[1- $\left.{ }^{14} \mathrm{C}\right]-\mathrm{D}$-glucose 6-phosphate in adipocytes incubated under the conditions of this study were examined according to the method of Olefsky [19]; no intracellular 2-deoxy-[1-14 C]-D-glucose was detected and essentially all the intracellular deoxyglucose was in phosphorylated form (chromatograms not shown). It has been well recognized that at high concentrations of extracellular glucose, transport may not be considered rate-limiting step for glucose metabolism [30-32]. Therefore, $0.1 \mathrm{mmol} / 1$ of glucose analogue was used in this study. It should also be pointed out that the concentration of insulin was $10 \mu \mathrm{U} / \mathrm{ml}$, which was much smaller than that usually reported in literature on glucose transport in isolated cells. At this low concentration of exogenous insulin, the rate of 2-deoxyglucose transport was not significantly different from the basal rate in the absence of hGH 4-15, and that enabled us to clearly demonstrate the effect of the hGH peptide. The adipocytes isolated from the hGH 4-15 treated animals showed a significant increase of 2 -deoxy-[1- $\left.{ }^{14} \mathrm{C}\right]-\mathrm{D}$-glucose transport in the absence or presence of exogenous insulin $(p<0.005)$. Exposure of the control cells in vitro to hGH $4-15$ for $30 \mathrm{~min}$ similarly stimulated glucose transport. Figure 1 shows the concentration-response curve of hGH 4-15 on in vitro glucose transport in the absence (basal) and the presence of exogenous insulin $(10 \mu \mathrm{U} / \mathrm{ml})$. Under basal conditions, significant effect on 2-deoxy-[1- $\left.{ }^{14} \mathrm{C}\right]$-D-glucose transport was observed at a concentration as low as $0.1 \mu \mathrm{g} / \mathrm{ml}(p<0.005)$, and maximal effect was almost reached at $10 \mu \mathrm{g} / \mathrm{ml}$ of hGH 


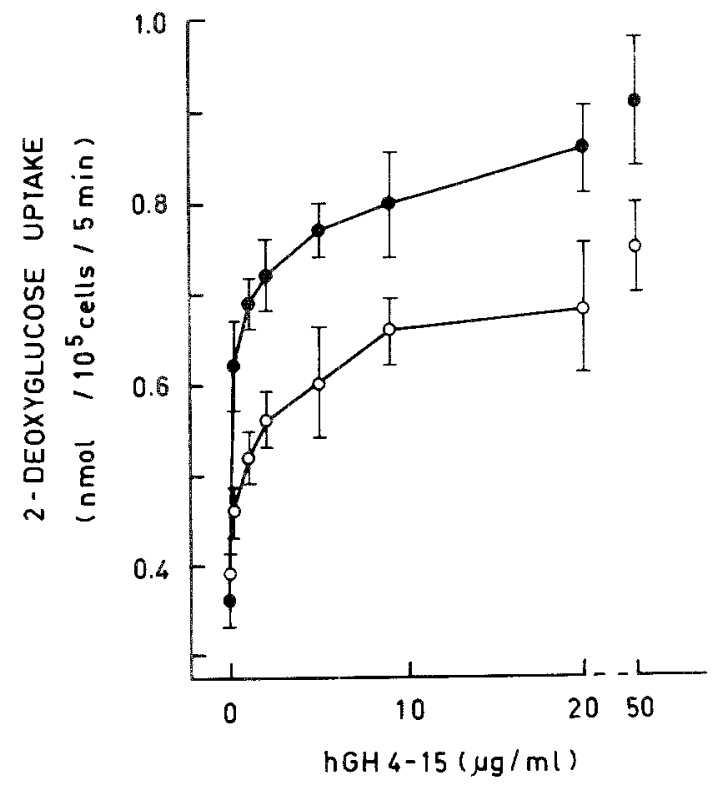

Fig. 1. Effect of varying concentrations of hGH 4-15 on in vitro uptake of 2-deoxy-[1-14 C]-D-glucose by rat adipocytes. After $30 \mathrm{~min}$ preincubation with hGH 4-15 at the concentrations indicated, cells were washed and incubated at $25^{\circ} \mathrm{C}$ for another $45 \mathrm{~min}$ in the absence (open circles) and the presence (filled circles) of insulin $(10 \mu \mathrm{U} / \mathrm{ml}$ ) before uptake assays. The assay procedure was the same as that described in Table 3. Results expressed as mean \pm SEM of three experiments carried out in quadruplicate

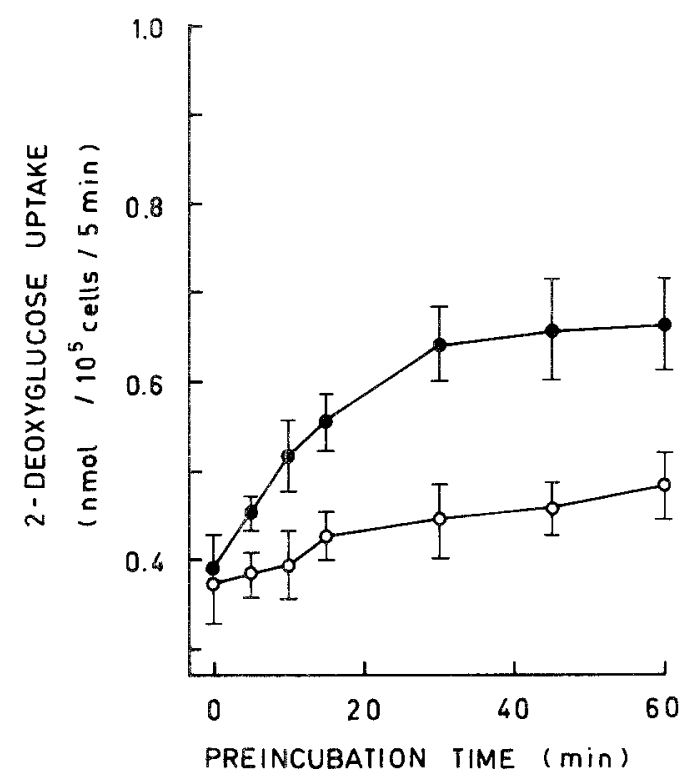

Fig. 2. Time course of the pre-incubation of hGH 4-15 on in vitro uptake of 2 -deoxy-[1-14 $\mathrm{C}]-\mathrm{D}$-glucose by rat adipocytes. After preincubation with hGH 4-15 $(10 \mu \mathrm{g} / \mathrm{ml})$ for time indicated, cells were washed and incubated in the absence (open circles) and the presence (filled circles) of insulin and assayed for 2-deoxyglucose uptake as described in Table 3. Values are mean \pm SEM of three separate experiments performed in quadruplicate

4-15. In the presence of exogenous insulin $(10 \mu \mathrm{U} / \mathrm{ml})$ the maximal stimulation by hGH $4-15$ was increased from $0.75 \pm 0.05$ to $0.91 \pm 0.07 \mathrm{nmol} / 10^{5}$ cells $/ 5 \mathrm{~min}$. Figure 2 suggested that a $30-\mathrm{min}$ preincubation ap- peared to be necessary for the optimal effect of the hGH peptide. The data further indicated that hGH 4-15 might have a direct effect on the transport system in adipocytes.

To verify the ability of hGH 4-15 to affect basal transport of 2-deoxy-[1- $\left.{ }^{14} \mathrm{C}\right]$-D-glucose, isolated adipocytes were pre-treated with anti-insulin sera. The hGH fragment at a concentration of $10 \mu \mathrm{g} / \mathrm{ml}$ gave a significant increase of 2-deoxyglucose transport of the serumtreated cells (Fig. $3, p<0.025$ ). Trypsinization destroys insulin receptors and virtually eliminates the effect of insulin on various metabolic functions in cells. Nevertheless, the present finding shows that hGH 4-15 slightly enhanced the transport of 2-deoxy-[1- $\left.{ }^{14} \mathrm{C}\right]-\mathrm{D}$-glucose by trypsinized adipocytes. Evidence clearly indicates that hGH 4-15 was able to enhance 2-deoxyglucose transport over the basal level.

Data also demonstrate that the specific glucose transport inhibitor, cytochalasin $\mathrm{B}$, abolished the stimulatory effect of hGH $4-15$ on 2-deoxy-[1- $\left.{ }^{14} \mathrm{C}\right]-\mathrm{D}$-glucose uptake. In addition, adipocytes pre-incubated with neuraminidase $(10 \mu \mathrm{g} / \mathrm{ml})$ at $37^{\circ} \mathrm{C}$ for $30 \mathrm{~min}$ failed to respond to hGH 4-15.

\section{Discussion}

Our previous studies have shown that the synthetic peptide hGH 4-15 induced hypoglycaemia in rats of different age groups [11]. Evidence also revealed that at the molecular level the synthetic peptide increased insulin receptor function and glycogen synthase activity [12]. The effect of the hGH 4-15 on glucose transport had not been firmly established. It is generally believed that the increase of insulin binding to plasma membrane receptors could result in alteration in transport processes [33]. However, the molecular relationship between insulin receptors and glucose transporters remains to be elucidated. Neuraminidase decreased glucose transport and oxidation without any inhibitory effect on insulin receptor binding [34-36]. Concanavalin A inhibited insulin binding but stimulated glucose transport $[37,38]$. Many other agents such as cytochalasin B and trypsin have been shown to have opposite effects on these two membrane-related metabolic regulators, namely the insulin receptor and the glucose transporter [39-42]. The present study is therefore essential in establishing unequivocally the effect of the amino-terminal sequence of hGH on glucose transport system of target cells. The initial findings revealed the similarities between in vivo and in vitro responses of the adipose tissues to $\mathrm{hGH}$ 4-15 in glucose oxidation, glycogen synthesis and lipogenesis, thus suggested that isolated adipocytes would be a suitable cell type for the studies on glucose transport. This was confirmed with the evidence that the in vivo effect of hGH 4-15 on 2-deoxyglucose transport in adipocytes remained in the subsequently isolated cells. 


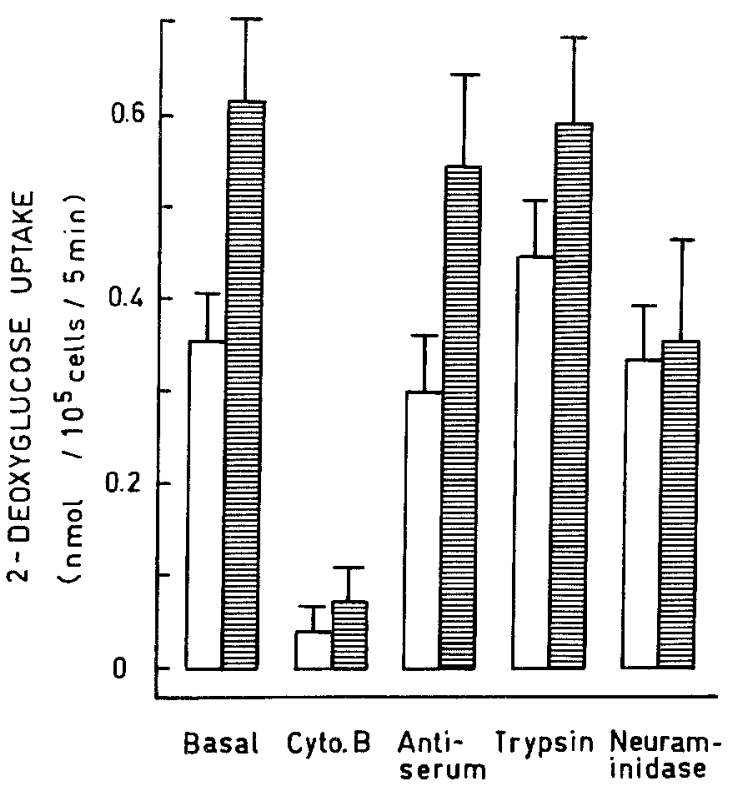

Fig. 3. Effect of hGH 4-15 $(10 \mu \mathrm{g} / \mathrm{ml})$ on 2-deoxy-[1- $\left.{ }^{14} \mathrm{C}\right]-\mathrm{D}$-glucose uptake of rat adipocytes pre-treated with either cytochalasin B $(25 \mu \mathrm{g} /$ $\mathrm{ml})$, anti-insulin antiserum $(3 \mu \mathrm{l} / \mathrm{ml})$, trypsin $(1 \mathrm{mg} / \mathrm{ml})$ or neuraminidase $(10 \mu \mathrm{g} / \mathrm{ml})$. Isolated cells were pre-incubated with the test agents at $37^{\circ} \mathrm{C}$ for $15-30 \mathrm{~min}$. The trypsin treatment of the adipocytes was terminated by adding soybean trypsin inhibitor $(1 \mathrm{mg} / \mathrm{ml})$. The treated cells were incubated for an additional $10 \mathrm{~min}$ before being washed twice with buffer. Cells treated with neuraminidase and other test agents were washed 3 times with buffer before use for the studies. The in vitro uptake experiments were performed on control cells (open columns) as well as the cells exposed to hGH 4-15 (shaded columns) as indicated in Table 4 . The data represent the mean \pm SEM of four separate experiments, each done in quadruplicate. Results indicate that the hGH peptide induced a significant difference in the uptake of 2-deoxyglucose in untreated (basal) cells $(p<0.025)$, cells treated with anti-insulin antiserum $(p<0.025)$ and trypsinized cells $(p<0.05)$. No significant difference was observed in cells treated with cytochalasin $B$ or neuraminidase

The present work demonstrates that the synthetic hGH 4-15 stimulates basal as well as insulin-stimulated 2-deoxyglucose transport of isolated rat adipocytes. The retention of increased transport rates in adipocytes of treated animals implies that the peptide has conferred a modification in the transport system. Currently the precise molecular mechanism underlying the action of hGH 4-15 on the transport system is not yet elucidated.

The in vitro results also clearly show that exposure of the isolated adipocytes to hGH 4-15 appears to bring about, through some as yet unknown mechanism, an increase of 2-deoxyglucose transport in the presence of submaximal concentration of exogenous insulin. The increase was related to the concentration of hGH 4-15, and maximum effect was observed at a concentration of $10 \mu \mathrm{g} / \mathrm{ml}$. The inhibition of 2-deoxyglucose transport by cytochalasin $B$ in both the absence and the presence of hGH 4-15 revealed that the hGH fragment has no effect in the absence of functional transporters. The neuraminidase data suggest that the transport proteins, presumably in the plasma membrane, might be involved the effect of the hGH 4-15. As the enhancing ef- fect of these amino-terminal fragments of hGH on insulin receptor function was well established in our previous studies [11,12], it was easy to speculate that the alteration in transport process could be a result of enhanced insulin binding to its receptor. However, the present data indicate that hGH 4-15 still stimulated 2-deoxyglucose transport in trypsinized adipocytes. As it is generally known that trypsin inactivates insulin receptor at plasma membrane and reduces insulin binding to isolated cells, this finding suggests that hGH 4-15 stimulated glucose transport independently from its effects of the insulin receptors. Experiments on adipocytes pretreated with anti-insulin anti-serum further confirmed that hGH 4-15 was able to stimulate 2-deoxyglucose transport in the cells by a mechanism which was independent of insulin. This is compatible with the observation on the effect of hGH 4-15 on trypsinized adipocytes. It is quite conceivable that hGH $4-15$, in addition to its effect on membrane receptors and transporters, acts upon a distal intracellular event in glucose metabolism.

The data in this study, together with our earlier findings [11], clearly show that the amino-terminal fragments of hGH enhance glucose transport, glucose utilization and insulin binding in rat adipocytes. Interestingly, hGH has recently been reported to have the same biological effect in vitro on adipocytes only after prolonged pre-incubation [43, 44]. Without prolonged preincubation, the adipocytes appeared to remain in the refractory state and failed to respond to the insulin-like actions of the intact hGH [45]. The precise mechanism to explain refractoriness in target cells is still obscure. Evidence from the present and the previous studies [8] on hGH fragments showed that isolated cells as well as intact animals responded rapidly to the actions of $h \mathrm{GH}$ 4-15. It is possible that the refractory state may be associated with a temporary impairment of the cellular mechanism to initiate the modulation of hGH into a functional confirmation or the proteolytic release of the active fragments of the hormonal molecule for the biological actions. However, our current observation is consistent with the concept that the amino-terminal region of the hGH molecule may be responsible for the insulin-potentiating action of the hormone. This concept is further supported by the recent observation by Forigeri that hGH 1-43 has potent insulin-potentiating action as reported by Lewis [10]. Further, the findings from the present studies with hGH 4-15 not only offer additional support that the insulin-potentiating fragments of hGH may have therapeutic potential in the treatment of diabetes mellitus, but also further our understanding of the molecular actions of intact hGH.

Acknowledgements. The authors wish to acknowledge the contributions of Ms. D.Heng and Ms. C. Pullin during the course of this research. The studies were supported by a project grant of National Health and Medical Research Council of Australia and a Special Research Fund Grant of Monash University, Victoria, Australia. 


\section{References}

1. Millman AE, Russell JA (1950) Some effects of purified pituitary growth hormone on carbohydrate metabolism in rat. Endocrinology $47: 114-128$

2. Mahler RJ, Szabo O (1969) Early insulin synergistic activity of growth hormone. Diabetes 18: 550-555

3. Baumann G, MacCart JG, Amburn K (1983) The molecular nature of circulating growth hormone in normal and acromegalic man: evidence for a principal and minor monomeric forms. J Clin Endocrinol Metab 56:946-952

4. Baumann G, Abramson EC (1983) Urinary growth hormone in man: evidence for multiple molecular forms. J Clin Endocrinol Metab 56:305-311

5. Paladini AC, Pena C, Poskus E (1983) Molecular biology of growth hormone. CRC Crit Rev Biochem 15: 25-56

6. Chawla RK, Parks JS, Rudman D (1984) Structural variants of human growth hormone. Ann Rev Med 34: 519-547

7. Ng FM, Bornstein J, Welker C, Zimmet PZ, Taft P (1974) Insulinpotentiating action of synthetic peptide relating to the amino terminal sequence of human growth hormone. Diabetes 23:943-949

8. Ng FM, Bornstein J (1979) Insulin potentiating action of a synthetic amino-terminal fragment of human growth hormone (hGH $1-15$ ) in streptozotocin-diabetic rats. Diabetes 28: 1126-1130

9. Singh RNP, Seavey BK, Lewis LJ, Lewis UJ (1983) Human growth hormone peptide 1-43: Isolation from pituitary glands. $J$ Protein Chem 2: 425-436

10. Lewis UJ (1984) Variants of growth hormone and prolactin and their post-translational modification. Ann Rev Physiol 46:33-42

11. Ng FM, Bornstein J (1982) Comparison of hypoglycaemic responses to human growth hormone and the synthetic 4-15 fragment between 16-18 day old and 45-50 day old rats. Diabetologia 23: $534-538$

12. Ng FM, Larner J (1976) Actions of insulin-potentiating peptides on glycogen synthesis. Diabetes $25: 413-419$

13. Sims P, Ng FM, Bornstein J (1980) Modulation of adipocytes insulin receptors by a human growth hormone fragment. Biochem Int $1: 120-125$

14. Ng FM, Bornstein J, Pullin CO, Bromely JO, Macaulay SL (1980) The minimal amino acid sequence of the insulin-potentiating fragment of human growth hormone. Diabetes $29: 782-787$

15. Pullin CO, Harcourt JA, Ng FM, Bornstein J (1981) The insulinpotentiating action of human growth hormone-synthesis and activity of N-terminal fragments. Int $\mathbf{J}$ Peptide Protein Res 18: 318-323

16. Ng FM, Henderson T, Bromley JO, Bornstein J (1983) Modulation of hepatic insulin receptors by a human growth hormone fragment (hGH 6-13). Mol Cellul Endocrinol 30: 63-71

17. Armstrong J, Bornstein J, Bromley JO, Macaulay SL, Ng FM (1983) Parallel insulin-like action of human growth hormone and its part sequence hGH 7-13. Acta Endocrinologia 103:479-486

18. Karnieli E, Hissin PJ, Simpson IA, Salans LB, Cushman SW (1981) A possible mechanism of insulin resistance in the rat adipose cell in streptozotocin-induced diabetes mellitus. J Clin Invest 68: 811-814

19. Olefsky JM (1978) Mechanisms of the ability of insulin to activate the glucose-transport system in rat adipocytes. Biochem $\mathrm{J}$ 172: 137-145

20. Martin BR, Denton RM, Pask HT, Randle PJ (1972) Mechanism regulating adipose tissue pyruvate dehydrogenase. Biochem J 129: $763-773$

21. Lawrence JC, Guinovart JJ, Larner J (1977) Activation of rat adipocyte glycogen synthase by insulin. $J$ Biol Chem $252: 444-450$

22. Rodbell M (1964) Metabolism of isolated fat cells. I. Effect of hormones on glucose metabolism and lipolysis. J Biol Chem 239: 375-380

23. Foley JE, Laursen AL, Sonne O, Gliemann J (1980) Insulin binding and hexose transport in rat adipocytes. Diabetologia 19: 234-241
24. Folch J, Lees M, Stanley GHS (1956) A simple method for the isolation and purification of total lipids from animal tissues. J Biol Chem 226: 497-509

25. Jungas RL (1964) Fatty acid synthesis in adipose tissue incubated in tritated water. J Biol Chem 239: 675-681

26. Ma GYW, Macaulay SL, Maggs JA, Armstrong JMcD, Bornstein $J(1982)$ The mechanism of the hypoglycaemic action of synthetic peptides related to the C-terminal sequence of human growth hormone. Biochim Biophys Acta 716: 400-409

27. Newman JD, Armstrong JMcD, Bornstein J (1978) Effect of part sequence of human growth hormone on in vivo hepatic glycogen metabolism in the rat. Biochem Biophys Acta 544: 234-240

28. Kobayashi M, Olefsky JM (1978) Effect of experimental hyperinsulinemia on insulin binding and glucose transport in isolated rat adipocytes. Am J Physiol 235: E53-E62

29. Gliemann J, Osterlind K, Vinten J, Gammeltoft S (1972) A procedure for measurement of distribution space in isolated fat cells. Biochem Biophys Acta 286: 1-9

30. May JM, Mikulecky DC (1983) Glucose utilization in rat adipocytes. J Biochem Chem 258: 4771-4777

31. Foley JE, Cushman SW, Salans LB (1980) Intracellular glucose concentration in small and large rat adipose cells. Am. $\mathbf{J}$ Physiol 238: E180-E185

32. Gliemann J, Rees WD, Foley JA (1984) The rate of labelled glucose molecules in the rat adipocyte dependence on glucose concentration. Biochim Biophys Acta 804: 68-76

33. Czech MP (1980) Insulin action and the regulation of hexose transport. Diabetes 29:399-409

34. Tsuda M, Taketomi S, Iwatsuka H (1980) Selective inhibition by neuraminidase of insulin/action on hexose metabolism of mouse adipocytes. Am J Physiol 239: E186-E191

35. Cuatrecasas P, Illiano G (1971) Membrane sialic acid and the mechanism of insulin action in adipose tissue cells. Effect of digestion with neuraminidase. J Biol Chem 246: 4938-4946

36. Tsuda M, Taketomi S, Iwatsuka H (1980) Selective inhibition by neuraminidase of insulin action on hexose metabolism of mouse adipocytes. Am J Physiol 239: E186-E191

37. Blackard WG, Small E, Ludeman C (1980) Inhibition of insulin binding by concanavalin A. Metabolism 29:691-697

38. Ludvigsen C, Jarett L (1982) Similarities between insulin, hydrogen peroxide, concanavalin $\mathrm{A}$, and anti-insulin receptor antibody stimulated glucose transport: Increase in the number of transport site. Metabolism 31: 284-287

39. Tannenbaum J, Tannenbaum SW, Godman GC (1977) The binding sites of cytochalasin D. J Cell Physiol 91: 239-248

40. Jarett L, Smith RM (1979) Effect of cytochalasin B and D on groups of insulin receptors and on insulin action in rat adipocytes. J Clin Invest 63: 571-579

41. Kono T, Barham FW (1971) Insulin-like effects of trypsin on fat cells. J Biol Chem 246: 6204-6209

42. Jarett L, Smith RM (1979) Effect of cytochalasin B and D on groups of insulin receptors and on insulin action in rat adipocytes. J Clin Invest 63: 571-579

43. Maloff BL, Levine JH, Lockwood DH (1980) Direct effects of growth hormone on insulin action in rat adipose tissue maintained in vitro. Endocrinology 107: 538-544

44. Goodman HM, Coiro V (1981) Induction of sensitivity to the insulin-like action of growth hormone in normal rat adipose tissue. Endocrinology 108: 113-119

45. Eden S, Schwartz J, Kostyo JL (1982) Effects of preincubation on the ability of rat adipocytes to bind and respond to growth hormone. Endocrinology 111: 1505-1512

Received: 16 June 1986; and in revised form: 7 October 1986

Dr. Frank M. Ng

Department of Biochemistry

Faculty of Medicine

Monash University

Clayton, Victoria 3168

Australia 